\title{
Spindle cell oncocytoma of the adenohypophysis in a woman: a case report and review of the literature
}

\author{
M Mlika $^{1 *}$, H Azouz $^{1}$, I Chelly ${ }^{1}$, I Ben Saïd ${ }^{2}$, H Jemel $^{2}$, S Haouet ${ }^{1}$, M Zitouna ${ }^{1}$, N Kchir ${ }^{1}$
}

\begin{abstract}
Introduction: Spindle cell oncocytoma of the adenohypophysis is a rare tumour recently reported by Roncaroli et al. in 2002. This tumour is considered a grade I tumour by the World Health Organization.

Case presentation: We describe what is, to the best of our knowledge, the 14th case of its kind in the literature. A 45-year-old African woman presented clinical and radiological findings related to a nonfunctioning pituitary adenoma. The diagnosis was made on the basis of histological and immunohistochemical findings.

Conclusion: The purpose of this work is to report a rare pituitary tumour and to describe its histological and immunohistochemical features, which were characterized by the expression of thyroid transcription factor 1 antigen by tumour cells. This fact could support the theory of a possible common origin of these tumours in pituicytomas. In fact, thyroid transcription factor 1 is considered to be a specific marker of pituicytes.
\end{abstract}

\section{Introduction}

Spindle cell oncocytoma (SCO) of the pituitary gland is a recently described entity which was recognized by the 2007 WHO Classification of Brain Tumours and considered a WHO grade I tumour [1]. It was initially described by Roncaroli et al. in 2002 [2], and only 14 cases have been reported in the literature. The histogenesis and prognosis of these tumours remain uncertain and need to be documented more thoroughly in the literature. Our aim is to report a new case of SCO and to describe its histological and immunohistochemical features supporting the theory of a possible common origin with pituicytoma [2].

\section{Case presentation}

We report the case of a 45-year-old African woman without a particular medical history who presented with intermittent decrease of visual acuity and headache. Cranial magnetic resonance imaging (MRI) revealed a solid adenohypophysis mass of $2 \times 1.5 \times 1 \mathrm{~cm}$ with suprasellar extension but no invasive growth. This mass showed

\footnotetext{
* Correspondence: mlika.zorgati.mona@hotmail.com

'Department of Pathology, La Rabta Hospital, Bab Saadoun, Tunis 2037,

Tunisia

Full list of author information is available at the end of the article
}

contrast enhancing in T1-weighted MRI scans (Figure 1). Laboratory tests used to explore pituitary disorders showed normal levels of pituitary hormones, including follicle-stimulating hormone (FSH) $(\mathrm{N}>20$ IU/L), luteinizing hormone $(\mathrm{LH})(\mathrm{N}>10 \mathrm{IU} / \mathrm{L})$, prolactin $(\mathrm{N}<20$ $\mu \mathrm{g} / \mathrm{L})$, corticotropin and thyrotropin. The diagnosis of nonfunctioning pituitary macroadenoma was suspected, and the tumour was completely resected via transsphenoidal surgery. No adjuvant therapy was administered. Postoperatively, the patient developed panhypopituitarism which has been managed by hormone substitution. In fact, laboratory tests showed marked low levels of FSH (5 IU/L), LH (2 IU/L), prolactin $(0.04 \mu \mathrm{g} / \mathrm{L})$, corticotropin $(10 \mathrm{nmol} / \mathrm{L})$, thyrotropin $(0.01 \mu \mathrm{U} / \mathrm{mL})$ and somatotropin. Otherwise, currently there is neither clinical nor radiological evidence of a recurrent tumor after a three-month follow-up period.

Microscopic findings consisted of a solid spindle cell neoplasm with increased cellularity. Tumour cells were spindled to epithelioids organized in interlacing fascicles. The tumour cells had eosinophilic and oncocytic cytoplasm (Figure 2A). Nuclear atypia and pleomorphism were absent. Mitotic count was estimated to 1 per 10 high-power field. There were neither microvascular proliferations nor necrosis. 


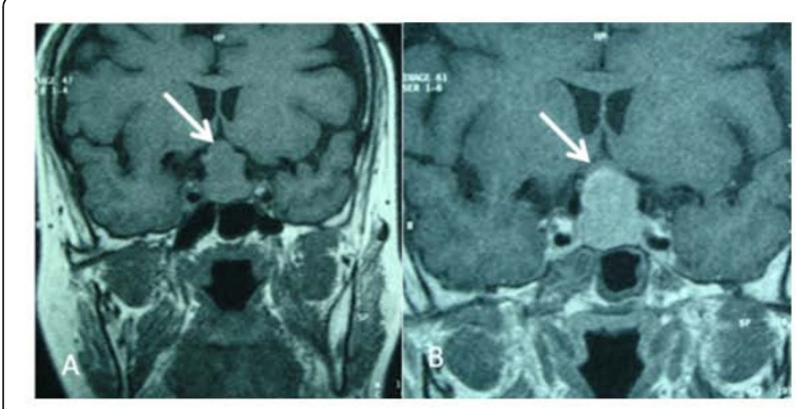

Figure 1 (A) Coronal magnetic resonance imaging studies showing a sellar mass with suprasellar extension but no invasive growth (arrow). (B) T1-weighted image showing the enhancement of the mass (arrow).

An immunohistochemical study showed that most tumour cells expressed S-100 protein (Figure 2B). Vimentin and epithelial membrane antigen (EMA) were similarly expressed by tumor cells (Figure 2C). There was no staining either with low-molecular-weight cytokeratin or with anterior pituitary hormones, including somatotropin, corticotropin, thyrotropin, FSH, LH and prolactin (Figure 2D). Tumour cells expressed the thyroid transcription factor 1 (TTF-1) antigen (Figure 3). Glial fibrillary acidic protein (GFAP) and CD68 were not expressed. Therefore, the diagnoses of glial tumour and granular cell tumour were ruled out. In light of these histological and immunohistochemical findings,

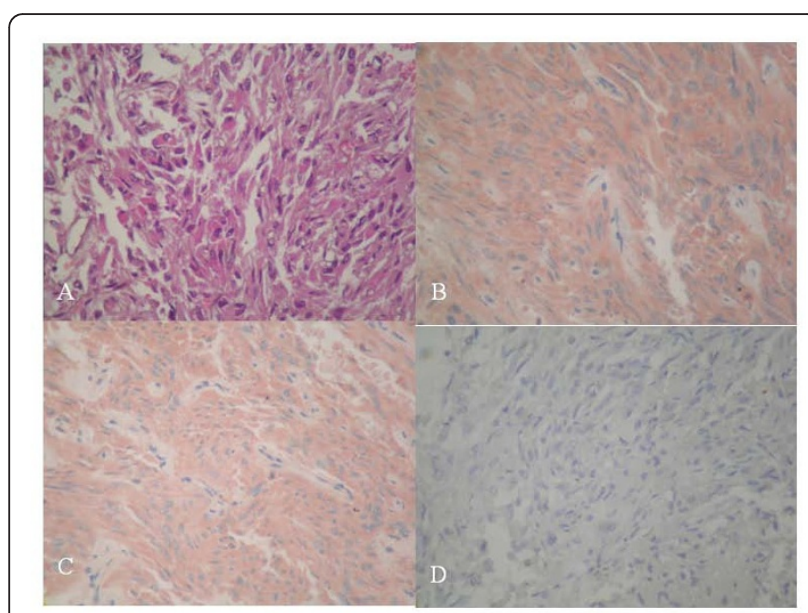

Figure 2 (A) Histology and immunoprofile of spindle cell oncocytoma. Spindle cell neoplasm with interlacing fascicles of spindled to epithelioid cells with eosinophilic and oncocytic cytoplasm (original magnification, $\times 400$; hematoxylin and eosin stain). (B) Immunohistochemical study showed that most tumor cells coexpressed S-100 protein (original magnification, $\times 400$; hematoxylin and eosin stain) and (C) vimentin and epithelial membrane antigen (original magnification, $\times 400$; hematoxylin and eosin stain). (D) Tumor cells were negative with pituitary hormones.

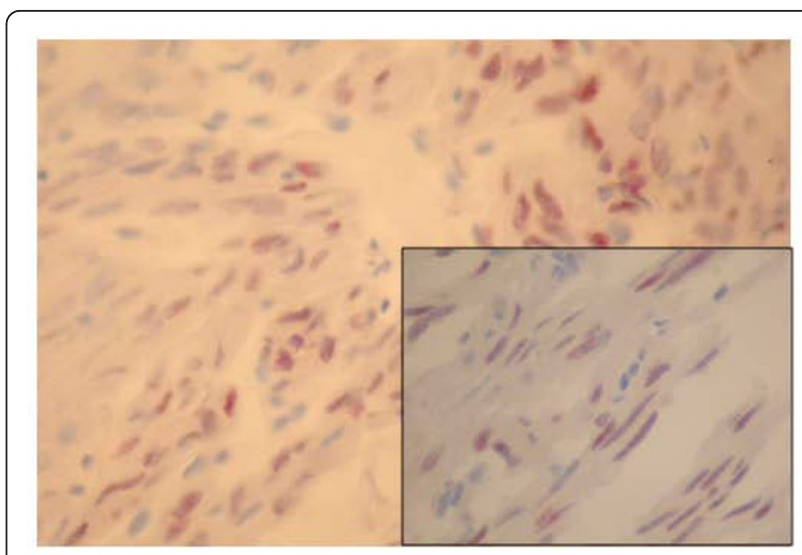

Figure 3 Nuclear expression of thyroid transcription factor 1 by tumour cells (original magnification, $\times 200$; hematoxylin and eosin stain). Inset: A higher-magnification image showing the nuclear expression (original magnification, $\times 400$; hematoxylin and eosin stain)

the diagnosis of SCO was strongly suspected. Ultrastructural examination showed neoplastic cells filled with mitochondria and well-formed desmosomes. These findings supported the diagnosis of SCO.

\section{Discussion}

SCO is a rare tumour, with only 14 cases reported in the English-language literature (Table 1). In accord with the present case, it affects middle-aged and older adults of both sexes. It presents as a sellar tumour suspected to be a functionally inactive macroadenoma.

\section{Imaging findings}

The radiological findings are nonspecific and do not differentiate these tumours from pituitary adenomas. In our case, they consisted of an enhanced mass of the sellar region.

\section{Histological and immunohistochemical features}

Histological examination is the only means of diagnosis [2-4]. This tumour is typically composed of interlacing fascicles of spindled to epithelioid cells with oncocytic cytoplasm. Mild to moderate nuclear atypia and even focal marked pleomorphism may be seen. The immunoprofile of these tumours is characterized by simultaneous positivity for S-100 protein, vimentin and EMA. Ultrastructurally, the neoplastic cells contain numerous mitochondria with lamellar cristae. The neoplastic cells are linked by intermediate junctions and desmosomes $[1,5]$.

\section{Pathogenesis}

These histological, immunohistochemical and fine structural features lead most authors to postulate a possible 
Table 1 Cases reported in the literature ${ }^{a}$

\begin{tabular}{|c|c|c|c|c|c|c|}
\hline $\begin{array}{l}\text { Year of } \\
\text { publication }\end{array}$ & Reference & $\begin{array}{l}\text { Number of } \\
\text { reported cases }\end{array}$ & $\begin{array}{l}\text { Sex ratio } \\
\text { (M/F) }\end{array}$ & $\begin{array}{l}\text { Mean age } \\
\text { (yr) }\end{array}$ & Symptoms & Evolution \\
\hline 2002 & Roncaroli et al. [2] & 5 cases & $3 / 2$ & 61.6 & Panhypopituitarism, visual defect & $\begin{array}{l}\text { No recurrence } \\
\text { (35.4 mo) }\end{array}$ \\
\hline 2005 & Dahiya et al. [3] & 2 cases & $2 F$ & - & Panhypopituitarism & No recurrence \\
\hline 2005 & Kloub et al. [4] & 2 cases & $1 / 1$ & 73 & - & Recurrence after 1 and $11 \mathrm{yr}$ \\
\hline 2006 & Vajtai et al. [5] & 1 case & $\mathrm{F}$ & 48 & $\begin{array}{l}\text { Adynamia, decrease of visual } \\
\text { acuity }\end{array}$ & No recurrence \\
\hline 2009 & Borota et al. [6] & 1 case & $\mathrm{F}$ & - & - & $\begin{array}{l}\text { Slow regrowth } \\
(30 \mathrm{mo})\end{array}$ \\
\hline 2009 & Demmsie et al. [7] & 1 case & M & - & Visual blurring, weight loss & Recurrence after 9 mo \\
\hline 2009 & Coiré et al. [8] & 1 case & $\mathrm{F}$ & 63 & Visual defect & Recurrence after 5 mo \\
\hline
\end{tabular}

${ }^{\mathrm{a} M}$, male; $F$, female.

derivation of these tumours from folliculostellate cells. Very little is known about the functioning of the folliculostellate cells. Some authors have reported that these cells are implicated in long-distance communication in the anterior pituitary gland [6-8]. These cells are known to coexpress the S-100 protein, vimentin and galectin 3 . These findings are shared by the SCO, but in our case tumour cells also expressed TTF-1. Lee et al. [9] described the expression of TTF-1 in eight cases of SCO. They reported that TTF-1 is generally expressed in fetal neurohypophysis. According to these findings, this marker could be specific to human pituicytes. The positivity of TTF-1 in our observation with these eight reported cases should lead to further research that could have implications for the classification of these rare sellar neoplasms and may indicate a similar origin of SCO and pituicytoma [9].

\section{Differential diagnoses}

The diagnosis of these tumours may be challenging. In fact, they should be distinguished from meningioma in its oncocytic variant, granular cell tumour, pituicytoma, oncocytic neoplasm arising from developmental salivary gland remnants and oncocytic variant of a pituitary adenoma [2-4]. Rarely, they should be distinguished from sellar schwannoma, but this tumour is very rare in that location [10]. Most meningiomas that are located within the cranial cavity occur over the cerebral convexities, but other common sites include para- and suprasellar regions. The radiological findings may be challenging when showing an enhancing mass without particular characteristics. The pathological findings and immunohistochemical features show a similar expression of EMA and vimentin, but S-100 protein is rarely expressed in meningiomas. Moreover, in opposition to $\mathrm{SCO}$, tumour cells in meningiomas are filled with intermediate filaments and desmosomal intercellular junctions in ultrastructural examination [2]. Granular cell tumours and pituicytomas tend to develop in the posterior pituitary gland rather than in the adenohypophysis. These tumours are thought to originate from pituicytes. Granular cell tumors are characterized by a granular cytoplasm which can be observed in SCO, but, in opposition to the SCO, granular cell tumour shows a strong expression of CD68. Besides, the cytoplasm of the granular cells is filled with phagolysosomes, and there are no mitochondria. The distinction from pituicytoma relies on the evidence of oncocytic change in SCO rather than GFAP staining patterns alone. Oncocytic neoplasms originating from salivary gland remnants express epithelial markers and lack S-100 protein and EMA positivity $[3,4]$. The distinction of SCO from an oncocytic variant of a pituitary adenoma is based on the expression of neurosecretory markers synaptophysin and chromogranin by the adenoma [5]. The differences in immunohistochemical profile between these tumours are illustrated in Table 2. The treatment of these tumours is based on surgical resection. Postoperative complications consist mainly of hypopituitarism as in the case of our patient. This complication is due to the difficulty of this surgery, which needs accurate management that is not always possible in the sellar region. A consensual protocol has not been assessed because of the complex issue of these tumours and the lack of large series. In fact, among the 14 cases reported in the literature, eight patients had a benign clinical course and six experienced recurrence despite adjuvant treatment in two cases [6].

\section{Conclusion}

SCOs of the pituitary gland are rare tumours whose pathogenesis and management remain debated because of the few numbers of reported cases. These tumours are considered to have a good prognosis despite the early recurrences reported in some cases $[8,9]$. Additional clinical follow-up is needed to assess the prognostic features. In our case, the period of follow-up was too 
Table 2 Immunohistochemical findings in spindle cell oncocytoma and the main differential diagnoses ${ }^{a}$

\begin{tabular}{ll}
\hline Diagnoses & Immunohistochemical markers \\
\hline Spindle cell oncocytoma & S-100 protein, vimentin and EMA are expressed \\
Oncocytic variant of meningioma & EMA is expressed, vimentin is expressed and S-100 protein is negative \\
Granular cell tumour & CD68 is expressed \\
Pituicytoma & GFAP is expressed \\
Oncocytic neoplasm originating from salivary gland remnants & Epithelial markers are expressed, S-100 protein and EMA are negative \\
Oncocytic variant of a pituitary adenoma & Synaptophysin and chromogranin are expressed \\
\hline
\end{tabular}

${ }^{a} E M A$, epithelial membrane antigen; GFAP, glial fibrillary acidic protein.

short, so we can only speculate whether such a tumour is benign.

\section{Consent}

Written, informed consent was obtained from the patient for publication of this case report and accompanying images. A copy of the written consent is available for review by the Editor-in-Chief of this journal.

\section{Acknowledgements}

We thank Dr Nadia Kourda from Charles Nicolle Hospital for her contribution in taking the photos.

\section{Author details}

'Department of Pathology, La Rabta Hospital, Bab Saadoun, Tunis 2037, Tunisia. ${ }^{2}$ Department of Neurosurgery, La Rabta Hospital, Bab Saadoun, Tunis 2037, Tunisia.

\section{Authors' contributions}

MM conceived of, coordinated with other coauthors and drafted and revised the manuscript. $\mathrm{HH}, \mathrm{IC}, \mathrm{IBS}, \mathrm{SH}, \mathrm{HJ}, \mathrm{MZ}$ and $\mathrm{NK}$ participated by acquisition and analysis of literature data and helped to draft the manuscript. All authors read and approved the final manuscript.

\section{Competing interests}

The authors declare that they have no competing interests.

Received: 4 March 2010 Accepted: 14 February 2011

Published: 14 February 2011

\section{References}

1. Louis DN, Ohgaki H, Wiestler OD, Cavenee WK: Tumors of the sellar region. WHO Classification of Tumours of the Central Nervous System. 4 edition. Lyon, France, International Agency for Research on Cancer 2007, 245-246.

2. Roncaroli F, Scheithauer BW, Cenacchi G, Horvath E, Kovacs K, Lloyd RV, Abell-Aleff P, Santi M, Yates AJ: 'Spindle cell oncocytoma' of the adenohypophysis: a tumor of folliculostellate cells? Am J Surg Pathol 2002, 26:1048-1055.

3. Dahiya S, Sarkar C, Hedley-Whyte ET, Sharma MC, Zervas NT, Sridhar E, Louis DN: Spindle cell oncocytoma of the adenohypophysis: report of two cases. Acta Neuropathol 2005, 110:97-99.

4. Kloub O, Perry A, Tu PH, Lipper M, Lopes MBS: Spindle cell oncocytoma of the adenohypophysis: report of two recurrent cases. Am J Surg Pathol 2005, 29:247-253.

5. Vajtai I, Sahli R, Kappeler A: Spindle cell oncocytoma of the adenohypophysis: report of a case with a 16-year follow-up. Pathol Res Pract 2006, 202:745-750.

6. Borota OC, Scheithauer BW, Fougner SL, Hald JK, Ramm-Pettersen J, Bollerslev J: Spindle cell oncocytoma of the adenohypophysis: report of a case with marked cellular atypia and recurrence despite adjuvant treatment. Clin Neuropathol 2009, 28:91-95.
7. Demssie YN, Joseph J, Dawson T, Roberts G, de Carpentier J, Howell S: Recurrent spindle cell oncocytoma of the pituitary, a case report and review of literature. Pituitary 2009.

8. Coiré $\mathrm{Cl}$, Horvath $\mathrm{E}$, Smyth $\mathrm{HS}$, Kovacs $\mathrm{K}$ : Rapidly recurring folliculostellate cell tumor of the adenohypophysis with the morphology of a spindle cell oncocytoma: case report with electron microscopic studies. Clin Neuropathol 2009, 28:303-308.

9. Lee EB, Tihan T, Scheithauer BW, Zhang PJ, Gonatas NK: Thyroid transcription factor 1 expression in sellar tumors: a histogenetic marker? J Neuropathol Exp Neurol 2009, 68:482-488.

10. Mohammed S, Kovacs K, Munoz D, Cusimano MD: A short illustrated review of sellar region schwannomas. Acta Neurochir (Wien) 2010, 152:885-891.

doi:10.1186/1752-1947-5-64

Cite this article as: Mlika et al:: Spindle cell oncocytoma of the adenohypophysis in a woman: a case report and review of the literature. Journal of Medical Case Reports 2011 5:64.

\section{Submit your next manuscript to BioMed Central and take full advantage of:}

- Convenient online submission

- Thorough peer review

- No space constraints or color figure charges

- Immediate publication on acceptance

- Inclusion in PubMed, CAS, Scopus and Google Scholar

- Research which is freely available for redistribution

Submit your manuscript at www.biomedcentral.com/submit
C Biomed Central 